funkcionářů a doporučovalo se obsazování všech pedagogických míst za pomoci konkurzu, diskutovalo se dokonce i o zavedení dvoustupňového studia - bakalářského a magisterského.

Studenti AMU patřili v období stávky v listopadu až prosinci 1989 mezi nejaktivnější a někteří z nich získali zaslouženě pověst skutečných studentských vůdců (např. student loutkoherectví Martin Mejstř́k). Po listopadu vzrostly pravomoci rektora, který nyní vykonával samostatně řadu činností, do nichž v minulosti zasahovalo ministerstvo školství. Byly ustaveny jednotlivé akademické rady fakult, které zpočátku společně tvořily rozšířenou akademickou radu rektora. Tyto rady se později transformovaly na akademické senáty jednotlivých fakult a zároveň vznikl i Akademický senát AMU. Výrazně se proměnila i Umělecká rada AMU, byli také rehabilitováni poškození pedagogové i studenti. V průběhu první poloviny devadesátých let došlo k výrazným proměnám podoby vysokého školství, které se promítly i do činnosti AMU, nap̌r. zavedení již zmíněného dvoustupňového vysokého školství.

AMU se v devadesátých letech opakovaně definovala jako vysoká škola univerzitního typu, jejíž neodmyslitelnou součástí se stalo i doktorské studium. Do nového tisíciletí nakonec vstoupila AMU jako stabilizovaná vysoká škola, která si dokázala udržet elitní úroveň výuky a úspěšně se prosazovala i v komplikovaných a neustále se měnících podmínkách českého školství.

Kniha je zakončena př́lohou, v níž je obsažen zakládací dekret AMU a medailonky rektorů. Nechybí ani seznam pramenů a literatury a jmenný a věcný rejstř́k.

Celkový př́nos publikace je zásadní $\mathrm{v}$ tom, že $\mathrm{k}$ dějinám AMU dosud nebyla zpracována žádná syntetizující historická práce. Předložená publikace na základě studia pramenů přehledně a detailně mapuje $\mathrm{v}$ souvislostech sedmdesátiletou historii této vzdělávací instituce v oblasti filmového, divadelního, hudebního a tanečního umění, která dala světu mnoho významných tvưrců. Dějiny AMU si tak snadno najdou cestu k odborné i laické veřejnosti.

Michal Továrek

doi: $10.14712 / 23365730.2021 .26$

\title{
Martin Franc - Lenka Krátká (edd.), Dějiny AMU ve vyprávěních
} Nakladatelství AMU, Praha 2017, 311 s., ISBN 978-80-7331-398-2

Recenzovaná kniha je jedním z výstupů interního projektu Akademie múzických umění, který byl v letech 2013-2016 zaměřen na dějiny této instituce. Obsahuje rozhovory s jejími osobnostmi (absolventy a pracovníky). Pro publikaci jich bylo vybráno 16 (z celkem 87 rozhovorů s 66 narátory). Autoři se snažili zachytit rovnoměrně vyprávění pamětníků ze všech tří fakult (DAMU, FAMU a HAMU). K nim bylo připojeno ještě interview s pracovnicí společného zařízení (Centrum pohybové př́ipravy, sportu a rehabilitace). Byla vybrána vyprávění zacílená v maximální možné míře na dění ve škole a šlo také o vyvážení jak různých oborů a generací, tak odlišných úhlů pohledu na historii instituce.

Knihu otevírají kapitoly „Jak kniha vznikala - metodologické a ediční poznámky“ a především „AMU v padesátých až devadesátých letech 20 . století očima narátorů - analýza“.1

1 Martin Franc - Lenka KrátKá (edd.), Dějiny AMU ve vyprávěních, Praha 2017, s. 17-54. 
Jedná se o interpretační studii, která vedle publikovaných rozhovorů cituje i rozhovory s osobnostmi, které se do hlavní části knihy nedostaly.

Díky svému speciálnímu zaměření i dobové atmosféře si AMU od samého počátku nemohla stěžovat na nedostatek zájemců o studium. Obrovský přetlak se zpočátku projevoval zejména na FAMU, kde se prijímacího rízení do prvního ročníku v roce 1946 zúčastnilo údajně kolem 1200 zájemců. Základní charakteristikou dění na AMU v prvních letech existence je dle mnohých chaos, který souvisel mimo jiné i s personální neukotveností nové instituce a s tvorbou vyučovacích osnov ,za pochodu“. Živelně vznikala i různá skripta a učebnice a vyučující pro některé obory se hledali těžko, mnohdy vyučovali i čerství absolventi. Odborná terminologie se teprve formovala, technické vybavení bylo navíc velmi primitivní. Netřeba dodávat, že skromná byla i prostorová situace.

Celkový zmatek ve výuce umocňoval roli formujících osobností, které ambiciózním studentům a studentkám sloužily jako skutečný maják. Neusazenost osnov umožňovala značnou volnost $\mathrm{v}$ pedagogických postupech, což samozřejmě mělo své odvrácené stránky, především chaos a nepravidelnost ve výuce.

Dalším výrazným prvkem je dle narátorů vztah $\mathrm{k}$ sovětskému umění a snahy o maximální sovětizaci výuky. Hovoří se hned o několika formách „přejímání sovětských zkušeností“ - např. v rámci studijních stáží českých odborníků a umělců v Sovětském svazu. Velmi časté byly i návštěvy sovětských poradců, odborníků či umělců v Československu.

Patrně nejvýraznější symbol sovětizace na AMU byla proslulá „Stanislavského meto-

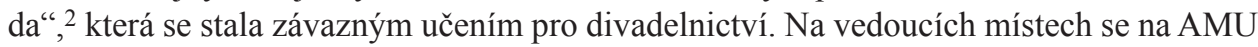
ocitly většinou osoby spojené s meziválečnou levicovou kulturní avantgardou, v mnoha př́ípadech vysoce vzdělaní lidé, kteří se rozhodně neuchylovali k prosazování nějakých primitivních ideologických frází. ${ }^{3}$

Roku 1956 došlo na AMU k různým vnitřním změnám, včetně prodloužení studia na pět let. Změnil se např. i průběh přijímacího řízení - přibyl požadavek doložit znalosti v jiných oborech, než na jaký se uchazeč hlásil, nebo důraz na všeobecný kulturní přehled.

Celkově došlo ke stabilizaci školy, patrná je také snaha více pracovat na jejím obrazu směrem $\mathrm{k}$ veřejnosti a řešit problémy nahromaděné $\mathrm{v}$ prvních letech činnosti školy. FAMU i ostatní fakulty prožívaly hlavně $\mathrm{v}$ šedesátých letech mimořádně úspěšná léta a jejich posluchači i absolventi se dokázali prosadit v náročné konkurenci v západní Evropě nebo v zámoří.

K další „přestavbě“ výuky došlo na přelomu padesátých a šedesátých let na základě požadovaného „spojení školy se životem“ a sjednocení učebních osnov s dalšími stejně zaměřenými vysokými školami v Československu. Byl zde také požadavek na rožšírení studia při zaměstnání a upevnění kázně a pracovní morálky studentů ve formě tzv. výrobní praxe a také nejrůznějších brigád, které probíhaly prakticky v celém období 1948-1989. I na AMU stejně jako v jiných oblastech společenského a kulturního života probíhalo uvolňování jen velmi pozvolně a v druhé polovině padesátých let se často mísilo otevírání průhledů do západní kultury s přežívajícím vzýváním sovětských vzorů. Na jednotlivých fakultách probíhaly různorodé projekce a besedy s umělci z východního bloku, ale i ze Západu.

2 Plné ztotožnění herce s rolí, kdy herec roli prožívá s důrazem na psychologické splynutí herce s postavou.

3 Např. taneční teoretik, kritik a pedagog Jan Reimoser, zakladatel výuky tance na AMU, nebo dramaturg František Götz. 
První výjezdy studentů (a pedagogů) v padesátých letech směřovaly především do Sovětského svazu a do zemí sovětského bloku, v šedesátých letech se již výrazně množily cesty do západní Evropy. V druhé polovině šedesátých let před srpnem 1968 se pak cestování na Západ hodně uvolnilo. Šedesátá léta přinesla také výrazný nárůst kontaktů se zeměmi tzv. třetího světa. Začal stoupat také počet zahraničních studentů na AMU, nejprve ze zemí východního bloku, na sklonku šedesátých let se pak objevili filmaři z tehdejší Jugoslávie.

Narátoři vzpomínají také na určitou emancipaci studentů a jejich četné konflikty s vyučujícími, které však v uvolněné éře šedesátých let nekončily nějakou fatální srážkou. I když jisté negativní dopady vyvolat mohly, konflikty nepřekročily čistě individuální rovinu. Také stávka na podzim roku 1968 nebyla směřována proti škole nebo pedagogům, vyučující ji spíše aktivně podporovali. Na šedesátá léta se většinou vzpomíná jako na dobu absolutně svobodnou, bez pocitu politických zábran a možností rozvíjet umělecké nadání. Při studiu hrála klíčovou roli diskuse, což zaručovalo kreativní a obohacující atmosféru mezi vyučujícími a studenty. Studenti ze šedesátých let ve srovnání se současností označují technické vybavení školy za víceméně primitivní, ačkoli dodávají, že i přes tento handicap tehdy vznikala kvalitní díla, především filmová.

Na vyučující i posluchače dopadla okupace Československa v srpnu 1968 a následné období označované jako normalizace mimořádně tvrdě a znamenala skutečný přelom. Došlo k prudkému poklesu respektu vedoucích politických představitelů kultury, bez ohledu na jejich názory a přesvědčení, což se neprríznivě podepsalo i na financování školy a jejím vybavení. Pedagogové, kteří se v reformním procesu aktivně angažovali, byli později perzekvováni a v mnoha př́padech museli školu opustit, mnozí situaci řešili odchodem do exilu. Ti, kteří zůstali, museli počítat s různými šikanami, které mizely až koncem osmdesátých let.

Následně na jednotlivé fakulty přišly „kádrové posily“, které měly zajistit ideologicky bezchybnou výuku, kvalita nově příchozích pedagogů byla často značně sporná. Na druhou stranu někteří vyučující, kteří na AMU přišli na počátku normalizace, se osvědčili. Nedá se však tvrdit, že by všichni akademičtí funkcionáři AMU ze sedmdesátých a osmdesátých let 20. století byli zavilými „,normalizátory“ a pronásledovali odlišné politické mínění. V osmdesátých letech se postupně ze školy ony „kádrové posily“ z počátku sedmdesátých let vytrácely.

Na některých katedrách i fakultách v sedmdesátých letech ideologové naráželi na rezistenci většiny studujících vůči panující ideologii, nebylo tedy možné hovořit o zcela úspěšně zvládnuté „,normalizaci“. Na sklonku osmdesátých let docházelo na DAMU k praktickému rozpadu SSM, který od svého vzniku na přelomu šedesátých a sedmdesátých let získal na fakultách jen málo členů.

I pro AMU přinesla normalizace výrazné omezení mezinárodních styků. Relativně nejméně byla $\mathrm{v}$ tomto ohledu postižena HAMU, kde zůstávala míra mezinárodních kontaktů na poměrně vysoké úrovni. Na zbývajících fakultách k výraznějším změnám $\mathrm{k}$ lepšímu dochází zhruba od druhé poloviny sedmdesátých let, kdy pedagogové, kteří nepatřili mezi perzekvované, mohli čas od času vyjíždět do západní Evropy či do zámoří.

Studenti FAMU a DAMU patřili v roce 1989 mezi hlavní hybatele mohutných společenských protestů. Revoluční atmosféra přinesla hlavně na DAMU a FAMU i jakousi studentokracii, či dokonce diktaturu studentů, kteří si nárokovali absolutní svobodu a ostře vyžadovali odchod neoblíbených pedagogů. Toto období vyvolává u některých narátorů 
dodnes nemalé rozpaky, stejně jako bouřlivé transformační dění v devadesátých letech a na počátku 21. století, kdy docházelo k četným organizačním proměnám.

Po úvodu následuje hlavní část knihy - 16 rozhovorů se 17 osobnostmi (v jednom př́ípadě se jedná o rozhovor se dvěma osobami naráz), ${ }^{4}$ které jsou řazeny podle jednotlivých fakult. Ke každému rozhovoru je připojen stručný životopisný medailon a fotografie narátora. Kniha obsahuje jmenný rejstř́k a anglické a české resumé.

Rozhovory s osobnostmi prrinášejí sice subjektivní pohled na dějiny této specifické vysokoškolské instituce, ale zároveň také podávají osobitá svědectví, díky nimž si čtenář může udělat představu o činnosti, vztazích a poměrech na pracovištích fakult AMU v různých obdobích. Kniha je také vhodným doplňkem k syntetizujícím dějinám AMU. ${ }^{5}$

Michal Továrek

doi: $10.14712 / 23365730.2021 .27$

\section{Marta Edith Holečková, Př́běh zapomenuté univerzity. Univerzita 17. listopadu (1961-1974) a její místo v československém vzdělávacím systému a společnosti}

Filozofická fakulta Univerzity Karlovy, Praha 2019, 202 s., ISBN 978-80-7308-921-4

Recenzovaná kniha se zabývá dějinami Univerzity 17. listopadu. Text knihy vychází z doplněné a mírně upravené disertační práce, kterou autorka ${ }^{1}$ obhájila v roce 2018 , a zabývá se tématem, které v dosavadní literatuře nebylo komplexně zpracováno.

V úvodu autorka popisuje volbu svého tématu a jeho vymezení. Nechybí zde ani zachycení současného obrazu Univerzity 17 . listopadu ve vzpomínkách pamětníků. Úvodní část uzavírá přehled pramenů a literatury.

První část knihy se nazývá Komunistické Československo a třetí svět a přináší popis zásadních momentů československé zahraniční politiky ve vztazích k zemím třetího světa. Zachycuje také Československo a Prahu v mezinárodních souvislostech. Československo bylo v poválečném období většinou evropských zemí vnímáno jako země blahobytu a vyspělého hospodářství. Leželo sice na okraji sovětského bloku, ale uprostřed Evropy,

4 Dana Stříbrná (nar. 25. 8. 1938), sekretářka Centra pohybové př́ípravy, sportu a rehabilitace AMU; Jan Císař (nar. 28. 1. 1932), dramaturg, kritik a pedagog, DAMU; Miloslav Klíma (nar. 22. 9. 1941), dramaturg a pedagog, DAMU; Nina Malíková (nar. 18. 10. 1945), pedagožka, DAMU a badatelka v oblasti loutkového divadla; Jan Vedral (nar. 20. 11. 1955), dramatik, dramaturg a pedagog, DAMU; Alena Zemančíková (nar. 18. 6. 1955), dramaturgyně, publicistka a autorka prozaických a dramatických děl, DAMU; Drahomíra Vihanová (nar. 31. 8. 1930), filmová režisérka a scénáristka, FAMU; Karel Vachek (nar. 4. 8. 1940), filmový režisér a pedagog, FAMU; Alois Fišárek (nar. 7. 1. 1943), stř̌ihač a pedagog, FAMU; Josef Hubka (nar. 18. 10. 1938), zvukový mistr, FAMU; Zdeněk Kopka (nar. 3. 6. 1932), filmový technik, FAMU; Lordan Zafranović (nar. 11. 2. 1944), filmový režisér, FAMU; Božena Brodská (nar. 27. 7. 1922), tanečnice, pedagožka a historička baletu, HAMU; Ivana Loudová (nar. 8. 3. 1941), hudební skladatelka, HAMU; Jiří Hlaváč (nar. 12. 10. 1948), klarinetista a saxofonista, HAMU; Eva Plochová (nar. 3. 2. 1955), sekretářka čtyř kateder HAMU; Jaromír Havlík (nar. 17. 5. 1950), hudební historik a teoretik, HAMU.

Martin Franc a kol., Dějiny Akademie múzických umění v Praze, Nakladatelství AMU, Praha 2017.

1 Marta Edith Holečková působí v Ústavu pro soudobé dějiny AV ČR, zabývá se samizdatem, metodou oral history a vysokými školami v ,socialistickém Československu“. 